\title{
UNIVERSITY OF THE THIRD AGE - UNIVERSITY STUDIES DON'T HAVE TO BE ONLY FOR THE YOUNG
}

\author{
Marcela Göttlichová \\ Dr., Faculty of Multimedia Communications, Tomas Bata University in Zlin (Czech Republic)
}

\begin{abstract}
The presented study focuses its attention on one of the important forms of lifelong learning, represented by the University of the Third Age, whose primary mission is to open up university resources to acquire knowledge, and skills for people at a post-productive age. The aim of the offered programs is to provide senior citizens with the opportunity to competently and at the university level to get systematically acquainted with the latest knowledge in science, history, politics, culture etc., i.e. to present a specific program of lifelong learning that would be interest-based. Students can thus broaden and enrich their knowledge with new skills, impressions, and experiences. The experience gained shows that the motivation to study at this later age is not only the joy of learning, but also the desire to maintain some mental freshness with a reflection in the increase of self-confidence based on their own active and creative approach to life, because older age may not be just an empty and lonely, but a full-fledged life stage. The objective of the study is not only to present the specifics of the University of the Third Age in Czech higher education, but also to present the approach of its students (University of the Third Age at Tomas Bata University in Zlin) to the offer of study programs, the structure of the studies, motivational aspects, etc., on the basis of a quantitative research in continuity with the resulting qualitative research values study, and at the same time to show one of the possibilities to make the presented form of education more effective.
\end{abstract}

Keywords: University education, lifelong learning, university of the third age, older age.

\section{Introduction}

An outstanding feature of today's society is the aging of the population, not only in the Czech Republic. It is not so long ago that old age was perceived negatively, and people in senior age were encouraged to be thought of as incompetent and useless members of the society, even considered to be a burden. However, the current view has been changing. It shows that old age does not have to just represent emptiness and loneliness, but it can be a full life stage, becoming a natural and integral part of the life cycle. One of the primary tasks of the society is to ensure dignified living conditions at the senior age (Haškovcová, 2010) in direct continuity with the active integration of seniors in all areas of social reality.

\section{Design}

The constant, increasing population growth in the 65+ age group is clearly evident throughout Europe. For the period 2000-2017, Italy $(18.1 \%, 22.3 \%)$, Greece $(17.3 \%, 21.5 \%)$, Germany $(16.2 \%$, $21.2 \%)$, Portugal $(16.0 \%, 21.1 \%)$ and Finland $(14.8 \%, 20.9 \%)$ occupied the forefront positions, where the Czech Republic ranked the sixteenth (Eurostat and CZSO, 2018). However, as the data of the Czech Statistical Office (CSO) show, there is a significant increase here as well. In 2000, the total number of population (in thousands) was 10,267 (4,997 men, 5,270 females), the population 65+ of which $1,423 / 13.9 \%$ (the index of old age $65+/ 0-14$ in $\%=85.5) 10,610(5,220$ men, 5,390 women), the population $65+$ of which $2,040 / 19,2 \%(122,1)$. In the last ten years, the number of people aged $65+$ has increased by about half a million. This indicator is also documented by indicators of increasing number of retirement pension recipients (RP) in the Czech Republic in 2006-2017 (men and women): 2006/622,154×797,865; $2017 / 848,008 \times 952,225$. Despite the fact that we can see the predominant number of women, the highest possible level $(11,000-11,999 \mathrm{CZK})$ in 2006 was only $11,282 / 1.4 \%$ of women, and $65,833 / 10.6 \%$ of men (2007: $23,225 / 2.7 \% \times 121,862 / 19.2 \% ; 2008: 64,565 / 7.8 \% \times 255,968 / 39.0 \%$ ), as in 2017 , when the highest possible amount (18,000 and more CZK) reached 7,363/0.8\% of women compared to 28,406/3.3\% of men (CSO, 2018). The problem is that an increasing proportion of senior citizens in the population becomes also the major cost item of the state budget, whether we are speaking of retirement pensions or the social and health care system. 
Thus, the solution to this situation becomes an increasingly important necessity not only for the society but also for the aging population entering the next stage of the postproductive age (Mühlpachr, 2005), because it can contribute, with its active approach, to a more effective transfer of experience and by generation conditioned cultural patterns, and last but not least the economic benefit (Drobný, Šerák, 2016). And especially in the development of seniors' activities, the firm place is represented by lifelong learning (LLL), primarily institutions linked to a formal school system, the so-called university of the Third Age (U3A) under the effective state aid. And although the results of some of the earlier studies have shown that senior citizens no longer have formal education, but on the contrary they identify with the active participation in informal learning (Rabušicová and Rabušic, 2008), and in their decision to 'educate' themselves they have played an important role (Šerák, 2009; Haškovcová, 2010; Veteška, 2016), on the contrary, it is increasingly important for the pensioners to focus on the desire to deepen, expand or acquire new knowledge with the preference of organized learning in continuity with the activities of educational institutions.

Universities of the Third Age have followed different models but two ideal types predominate: the French model (1973), based on close association with a traditional university; and the British model (1981), operating more in the spirit of mutual aid and self-help (Dannefer, Phillipson, 2010). The U3A system in the Czech Republic (1989) is built on the French model. At present the U3A is already at 40 universities and faculties across the Czech Republic. Since 1993, they have been associated in the Association of Third Age Universities (AU3V), a member of AIUTA (International Association of the Universities of the Third Age), EFOS (European Federation of Older Students), and the European information network for the U3As (Šerák, 2013).

\section{Methods}

A primary research was conducted at Tomas Bata University (TBU) in Zlín, which is a full member and at the same time the seat of the AU3A. the U3A at TBU offers one-year lecture cycles (the 1st year of study - "Basic U3A course") with the possibility of choosing subjects from the accredited study fields/lectures for the given academic year. The study subjects are two-semester and four-semester courses. Teaching takes place once every 14 days, mainly in the form of two-hour lectures (seminars or workshops). In the academic year 2017/18, within the framework of accredited U3A study programs (lectures: natural and technical sciences; social sciences; teachings and services; law, legal and public administration; psychology; culture and arts, art work; photography; linguistic courses; informatics and physical activities) the total of 1,521 U3A students participated (Annual Report 2017, 2018).

A quantitative research survey took place in December 2018 as a part of the 4th year of the Cultural History $(\mathrm{CH})$ study program in the form of a physical questionnaire containing 33 questions $(21 \mathrm{closed} / 4$ polyatomic, 7 semi-open and 5 open), supplemented by a subsequent discussion. Out of the total of 58 attenders, $46 / 79 \%$ (4 men and 42 women) participated in the survey, out of which only $1 / 2 \%$ did not reach the age of 60 years (without RP), 21/46\% (61-70 years of age) and 24/52 \% (71-80 years of age). Secondary education completed with a Maturita exam had been reached by $29 / 63 \%$ of respondents (formerly having been employed particularly in administration), and higher education by $17 / 37 \%$ of respondents (predominantly working in technical and pedagogical direction).

\section{Discussion}

As stated, it is above all a motivation in continuity with teaching, which play the primary role in the educational process and will be at the center of attention as well as within the contribution. The strongest motivation to enter the U3A were for the respondents their personal interests $(35 / 76 \%)$, as well as the desire for knowledge (35/76\%), the desire to keep up (12/26\%), and to be more involved in the society $11 / 24 \%$ ), which directly corresponds to the current requirements (see 2) and where the attention of the U3A should be addressed. Although motivation remains also to be the need to fill up free time $(11 / 24 \%)$, friends $(6 / 13 \%)$ and family $(1 / 2 \%)$, it is not only "a" time filler but the preference for a full-fledged educational process leading to the transfer of information on a professional basis. And as the responses showed, 40/87\% of the respondents mentioned motivation in the form of lecturers (access, expertise). For the overwhelming majority (29/64\%) of the respondents, the admittance into the U3A was no longer a major change in life, and the current demandingness of the study was classified mainly as less demanding $(31 / 67 \%)$, the number decreased for moderate difficulty $(12 / 26 \%)$, and only three $(7 \%)$ respondents regarded the study to be difficult in continuity with stress. Nevertheless, the satisfaction with the education was $100 \%$, while the preferences were for the presentation of teachings in the form of a lecture (36/78\%), the form of a discussion $(21 / 46 \%)$, and the third place was given to an individual lecture (18/39\%). There was also a great interest in the possibility of frequent excursions and educational field trips $(35 / 76 \%)$ corresponding to the lectured 
matter, in the organization of which they actively take their part. And it is also an organization of exhibitions presenting their own artwork or the works of their colleagues, etc. The respondents unequivocally proved their interest in continuing in studying (eg the $\mathrm{CH}$ program out of a student initiative has been running smoothly for 4 years), but if it was necessary to consider interrupting or dropping out of the study, for $40 / 87 \%$ the only reason would be their health conditions, for the $4 / 11 \%$ a loss of interest, and the only (2\%) answer mentioned the financial situation. They also contribute to the popularization of the U3A in public, and for the overwhelming majority, the source of information on the U3A coming from their neighborhoods and friends (30/67\%), family (9/20\%), the Internet was mentioned the least $(5 / 11 \%)$, although only respondent said they did not use the computer at all. Even the conclusions of the discussion confirmed that the U3A studies primarily bring "the respondents to expanding knowledge, personality development, self-education, knowledge of new horizons beyond their former occupations, etc.".

Thus, we can consider the active attitude of the elderly students not only within the study activities conditioned by the pursuit of education, but also outside the 'study duties' to be a beneficial contribution. We should talk about the 'commitment' to further support these activities, enable senior learners to formulate their needs and requirements, create the conditions for their active participation in the design and implementation of programs and projects, and encourage the development of their creative potential. And the emphasis should also be placed on the development of intergenerational cooperation between young university students and senior citizens in order to share their experience.

\section{Conclusion}

Although a cause-effect relationship between intellectual challenge in later life and an individual's ability to continue to function effectively may remain difficult to establish, the empowering nature of education provides a convincing rationale for increasing the range of opportunities for older people (Svindel, Thompson, 1995). We still find that the attention paid to the education of the elderly is only marginal in the educational process, and its importance remains very often underestimated. If we want the life to be successful in today's "knowledgeable society", it becomes necessary to strengthen the active approach and, in particular, the motivation for lifelong learning. That is, the need to raise interest in the permanent expansion of the educational and skill base, even at the post-productive age. In order for a change to take place, and for people to accept learning and education as a normal part of their lives (even at the late age), it is necessary to think about how to motivate them to develop, explore educational opportunities and remove the barriers that prevent their participation in education. The segment of education of the elderly certainly deserves its increased attention.

\section{References}

Annual Report. (2017, 2018). Tomas Bata University. https://www.utb.cz/univerzita/urednideska/ruzne/vyrocni-zpravy/. (Accesssed: 19. February 2019)

Eurostat. (2018). Senior citizens. Your key to European statistics. Czech Statistical Office (CSO) 11.12.2018. https://www.czso.cz/csu/czso/seniori (Accesssed: 16. January 2019)

Czech Statistical Office. (2018). Recipients of old-age pension by size and sex in the Czech Republic. Tab. 13.06, Selected demographic data in the Czech Republic. Tab. 01.01, 11.12.2018. https://www.czso.cz/documents/10180 (Accesssed: 16. January 2019)

Drobný, T. \& ŠERÁK, M. (2016). Senioři v muzeu. Metodický materiál. Brno: MZM.

Dannefer, D. \& Phillipson, Ch. (eds) (2010). The Sage Handbook of Social Gerontology, Sage Publications, London, 2010, $712 \mathrm{pp}$.

Haškovcová, H. (2010). Fenomén stáří. Praha: Havlíček Brain Team.

Mühlpachr, P. (2004). Gerontopedagogika. Brno: Masarykova univerzita v Brně.

Rabušicová, M. \& Rabušic, L. (2008). Učíme se po celý život? Brno: Masarykova univerzita v Brně.

Swindell, R. \& Thompson, J. (1995). An international perspective on the university of the third age. Educational Gerontology, 21, 429-447.

Šerák, M. (2009). Zájmové vzdělávání dospělých. Praha: Portál.

Šerák, M. (2013). Měnící se role vzdělávání seniorů v akcelerujícím světě. In: Starzenie sie i starość w dynamicznie szmieniajacym sie świecie. Praha: Ofyciny Wydawnicza „Humanitas“.

Veteška, J. (2016). Přehled andragogiky: úvod do studia vzdělávání a učení se dospělých. Praha: Portál. 